\title{
Sequences Analysis of ITS Region and 18S rDNA of Ulva
}

\author{
Zijie Lin, Zhongheng Lin, Huihui Li, and Songdong Shen \\ College of Life Sciences, Soochow University, Suzhou 215123, China \\ Correspondence should be addressed to Songdong Shen, shensongdong@suda.edu.cn
}

Received 23 February 2011; Accepted 7 April 2011

Academic Editors: J. Elster and H. Sanderson

Copyright ( 2012 Zijie Lin et al. This is an open access article distributed under the Creative Commons Attribution License, which permits unrestricted use, distribution, and reproduction in any medium, provided the original work is properly cited.

\begin{abstract}
Ulva, as the main genera involved in green tides in the Yellow Sea, has attracted serious concern in China. Especially, Ulva prolifera is one of the causative species of the occurring. This paper focused on the complete sequences analyses of ITS, 18S, and the combined data to determine phylogenetic relationships among taxa currently attributed to Ulva, Monostroma, and some other green algal. The samples are all concluded in the area of Yellow Sea, China. The results showed the content of G+C in $18 \mathrm{~S}$ was approximately concentrated upon $49 \%$ in average of 19 subjects while the ITS region content of base G and C is obviously higher than A and T. Comparing the ITS and $18 \mathrm{~S}$ rDNA sequences obtained in this paper to other species retrieved from GenBank, the genetic distance and the ratio of sequence divergence reflect that $U$. pertusa and U. prolifera had closer genetic relationship with an $18 \mathrm{~S}$ rDNA, which had genetic distance of 0.007 while ITS had further genetic distance. According to further comparison, Ulva prolifera has closest genetic distance with Chloropelta caespitosa (0.057) and Ulva californica (0.057), which is a reverification coincided Chloropelta, Enteromorpha, and Ulva are not distinct genera.
\end{abstract}

\section{Introduction}

Green tide is an ecological phenomenon that occurs globally in which fixed growth alga break away from the shallow beaches of calm bays, resulting in accumulation of extensive biomass of free-floating green alga $[1,2]$. Eutrophication is the main reason for green tide $[3,4]$. The main species involved in green tides are Ulva sp. and Enteromorpha sp. Large scale green tides have occurred continuously four times in the Yellow Sea, from 2007 to 2010 in China, [5, 6], which had serious influences on the local environment and the life of coastal residents. As well known, these green tides consist of Enteromorpha sp. [7, 8]; however, their sources are still subject to debate. It has been suggested that the southern coast of the Yellow Sea is the ultimate source; accordingly, this region has become the focus of many investigations into the subject [9]. Ulva sp. has been considered the main causative species of green tides, which have bloomed continuously in recent years in the central and southern Yellow Sea in China. Enteromorpha [10] belongs to Ulvaceae, Ulvales, Chlorophyceae, Chlorophyta. More than 100 species of this organism have been recorded worldwide; however, only about 30 species can be recognized based on their morphology [11]. In addition, 23 species of Enteromorpha have been recorded in China [12-16]. Most of them are marine species, which are widespread along the coast of China.

Due to the divergence of Enteromorpha or Ulva, the Ulva sp. is named according to Tan et al. [20] and Hayden et al. [21] in this study. Ulva sp. has wide acclimatization and can grow well in a broad range of temperatures and salinities, but the morphological characteristics are changing easily in response to the environment [16]. Various morphological changes in the intraspecies and less differences that are difficult to identify, even among interspecies. Therefore, making an identification of Ulva sp. by using classical taxonomic methods is very difficult $[22,23]$. Molecular biology and cross-hybridization methods $[24,25]$ have been introduced into this field to clarify the species. By this method, some reports have suggested that green tides are formed by an Ulva linza-procera-prolifera (LPP) complex instead of individual species $[5,26]$. Analyses of nuclear ribosomal internal transcribed spacer DNA (ITS nrDNA; 29 ingroup taxa including the type species of Ulva and Enteromorpha), the chloroplast-encoded $\mathrm{rbcL}$ gene (for a subset of taxa), and a combined dataset were carried out. Combined with 
TABle 1: Primers used for PCR amplification and sequencing.

\begin{tabular}{lccl}
\hline Gene & Region and direction & Primer name & Sequence $\left(5^{\prime}-3^{\prime}\right)$ \\
\hline ITS region & $5^{\prime}$ end $(\mathrm{F})$ & $\mathrm{F}$ & TCT TTG AAA CCG TAT CGT GA \\
18S rRNA & $3^{\prime}$ end $(\mathrm{R})$ & $\mathrm{R}$ & GCT TAT TGA TAT GCT TAA GTT CAG CGG GT \\
& $5^{\prime}$ end $(\mathrm{F})$ & $\mathrm{NS} 1^{1}$ & GTA GTC ATA TGC TTG TCT C \\
& $\sim 1150(\mathrm{R})$ & $\mathrm{NS} 4^{1}$ & CTT CCG TCA ATT CCT TTA AG \\
& $\sim 1150(\mathrm{~F})$ & AAC TTA AAG GAA TTG ACG GAA G \\
& $3^{\prime}$ end $(\mathrm{R})$ & $\mathrm{NS} 8^{1}$ & TCC GCA GGT TCA CCT ACG GA \\
$5^{\prime}$ end $(\mathrm{F})$ & CRN5 ${ }^{2}$ & TGG TTG ATC CTG CCA GTA G \\
& $\sim 1137(\mathrm{R})$ & GTG CCC TTC CGT CAA T \\
& $\sim 337(\mathrm{~F})$ & GGAGGATTAGGGTCCGATTCC \\
& $\sim 1131(\mathrm{R})$ & AB1 & CTTCCGTCAATTCCTTTAAG \\
& $\sim 1056(\mathrm{~F})$ & TW ${ }^{3}$ & GCGGGTGTTTGTTGA \\
& Mons & CTATTTAGCAGGCTGAGGT \\
\hline
\end{tabular}

${ }^{1}$ From White et al. [17], ${ }^{2}$ from Booton et al. [18], ${ }^{3}$ from Van Oppen [19].

earlier molecular and culture data, these data provide strong evidence that Ulva, Enteromorpha, and Chloropelta are not distinct evolutionary entities and should not be recognized as separate genera [21]. Partial sequences of the genes coding for $\mathrm{rbcL}$ and the $18 \mathrm{~S}$ rRNA were used to determine the phylogenetic position of the order Prasiolales among other members of the Chlorophyta. Sequence divergence values within the Prasiolales for the rbcL gene (0-6.1\%) and the $18 \mathrm{~S}$ rRNA gene (0.4-3.8\%) are both low compared to values among the other green algal sequences. Parsimony and distance analyses of the two subject genes sequences indicate that the Prasiolales is a well-delineated order of green algae containing both Prasiola and Rosenvingiella [27].

In this study, complete sequences of ITS and 18S are used to analyze the phylogenetic relationship among three common species (Ulva prolifera, Ulva pertusa, and Monostroma grevillei) in the Yellow Sea, China and some other green algal around the world. Especially, Ulva prolifera is the main causative species of green tides in China. Assessing the phylogenetic position of Ulva contributes to the investigation of the process of phylogenetic.

\section{Material and Methods}

2.1. Plant Material. Ulva prolifera were collected from Lianyungang coast of Jiangsu Province. And Monostroma grevillei and Ulva lactuca were collected from Qingdao coast of Shandong Province. Thallus were cleaned up, dried, and stored at $-20^{\circ} \mathrm{C}$ for further analysis. The samples were reanimated several hours to unfold entirely and then soaked in $0.7 \% \mathrm{KI}$ solution for ten minutes, followed by scouring with $\mathrm{ddH}_{2} \mathrm{O}$.

2.2. DNA Extraction. The cleaned-up samples were stored at $-70^{\circ} \mathrm{C}$ overnight and then were triturated thoroughly with a chilled mortar and pestle. They were transferred into microcentrifuge tubes, which $2 \%$ sea snail enzyme with $2 \mathrm{M}$ glucose was added into. The samples were digested for three hours at $25^{\circ} \mathrm{C}$ in swing bed and then were filtered and collected. Total genomic DNA was extracted by CTAB method, which was modified according to the samples. In brief, each sample was suspended with DNA extraction solution $(3 \%$ CTAB, $0.1 \mathrm{~mol} \mathrm{~L}^{-1}$ Tris- $\mathrm{HCl}$, pH 8.0, $0.01 \mathrm{~mol} \mathrm{~L}^{-1}$ EDTA, $1.4 \mathrm{~mol} \mathrm{~L}^{-1} \mathrm{NaCl}, 0.5 \% \beta$-mercaptoethanol, $\left.1 \% \mathrm{PVP}\right)$ and digested with protease-K with a final concentration of $300 \mu \mathrm{g} \mathrm{mL}^{-1}$. The mixture was incubated at $55^{\circ} \mathrm{C}$ for half an hour with shaking every ten minutes, and then it was cooled down to room temperature. One-third volume of $5 \mathrm{M}$ KAc was mixed with the solution before extracting the protein with phenol:trichloromethane: isoamyl-alcohol (25:24:1 $\mathrm{v} / \mathrm{v} / \mathrm{v})$. The extract was precipitated by isopropyl-alcohol at $-20^{\circ} \mathrm{C}$ for two hours. The solution was centrifuged and then the sediment was collected and cleaned with $70 \%$ ethyl alcohol. Finally, the sediments were dissolved in TE buffer $\left(10 \mathrm{mmol} \mathrm{L}^{-1}\right.$ Tris- $\mathrm{HCl}, \mathrm{pH} 8.0,1 \mathrm{mmol} \mathrm{L}^{-1}$ EDTA) and could be used as template for the following PCR amplification.

2.3. PCR Amplification and Purification. The primers F\&R were designed according to ITS region sequence and MonS \& MonA were designed according to $18 \mathrm{~S}$ rDNA sequence retrieved from software Primer 5.0. And the primers were synthesized by Shanghai Sangon Biological Engineering Technology and Service Co., Ltd. (Table 1).

The reactions for PCR amplification were performed

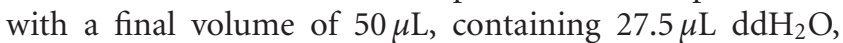
$10 \mu \mathrm{L} 5 \times$ ExTaq Buffer $\left(\mathrm{Mg}^{2+}\right), 6 \mu \mathrm{L}$ dNTPMix $(2.5 \mathrm{mM})$, $5 \mu \mathrm{L}$ of the DNA template, $2 \mu \mathrm{L}$ of each PCR primer $\left(50 \mathrm{pmol} \mu \mathrm{L}^{-1}\right)$, and $0.5 \mu \mathrm{L}$ ExTaq DNA polymerase $\left(5 \mathrm{U} \mu \mathrm{L}^{-1}\right)$.

The amplification of ITS region was performed with an initial denaturation at $94^{\circ} \mathrm{C}$ for $5 \mathrm{~min}, 35$ cycles at $94^{\circ} \mathrm{C}$ for $1 \mathrm{~min}, 45^{\circ} \mathrm{C}$ for $2 \mathrm{~min}$, and $65^{\circ} \mathrm{C}$ for $3 \mathrm{~min}$. And the products of amplification were preserved in $4^{\circ} \mathrm{C}$.

The amplification of $18 \mathrm{~S}$ rDNA was performed with an initial denaturation at $95^{\circ} \mathrm{C}$ for $2 \mathrm{~min}, 35$ cycles at $95^{\circ} \mathrm{C}$ 
TABLE 2: List of species used in this study and GenBank accession numbers for ITS and $18 \mathrm{~S}$

\begin{tabular}{|c|c|c|}
\hline Taxon & ITS accession number & $\begin{array}{c}\text { 18S rRNA accession } \\
\text { number }\end{array}$ \\
\hline Ulva lactuca & AY422499 & AF499666 \\
\hline $\begin{array}{l}\text { Klebsormidium } \\
\text { flaccidum }\end{array}$ & EU434019 & M95613 \\
\hline Chlorella vulgaris & FM205855 & X13688 \\
\hline $\begin{array}{l}\text { Mantoniella } \\
\text { squamata }\end{array}$ & FN562451 & X73999 \\
\hline Ulva prolifera & HQ902007 & HQ850569 \\
\hline $\begin{array}{l}\text { Monostroma } \\
\text { grevillei }\end{array}$ & HQ902006 & HQ850570 \\
\hline $\begin{array}{l}\text { Paulschulzia } \\
\text { pseudovolvox }\end{array}$ & AF182428 & U83120 \\
\hline $\begin{array}{l}\text { Trebouxia } \\
\text { asymmetrica }\end{array}$ & AF344177 & Z21553 \\
\hline $\begin{array}{l}\text { Kornmannia } \\
\text { leptoderma }\end{array}$ & AF415168 & AF499661 \\
\hline $\begin{array}{l}\text { Monostroma } \\
\text { nitidum }\end{array}$ & AF415170 & AF499665 \\
\hline Blidingia minima & AJ000206 & AF499659 \\
\hline $\begin{array}{l}\text { Enteromorpha } \\
\text { intestinalis }\end{array}$ & AJ000210 & AF189077 \\
\hline Ulva fenestrata & AJ234316 & AF499653 \\
\hline $\begin{array}{l}\text { Chloropelta } \\
\text { caespitosa }\end{array}$ & AY016309 & AF499656 \\
\hline $\begin{array}{l}\text { Ulvaria obscura } \\
\text { var. blyttii }\end{array}$ & AY260571 & AF499657 \\
\hline Ulothrix zonata & Z47999 & AY278217 \\
\hline Ulva pertusa & HQ902008 & HQ850571 \\
\hline Ulva californica & AY422518 & AF499652 \\
\hline $\begin{array}{l}\text { Percursaria } \\
\text { percursa }\end{array}$ & AY016305 & AF499658 \\
\hline
\end{tabular}

for $1 \mathrm{~min}, 55^{\circ} \mathrm{C}$ for $1 \mathrm{~min}$ (while the $\mathrm{AB} 1 \& \mathrm{TW} 4$ was $50^{\circ} \mathrm{C}$ and the MonS\&MonA is $44^{\circ} \mathrm{C}$ ), $72^{\circ} \mathrm{C}$ for $4 \mathrm{~min}$, and a final extension step at $72^{\circ} \mathrm{C}$ for $6 \mathrm{~min}$. And the products of amplification are preservation in $4^{\circ} \mathrm{C}$.

The PCR products were confirmed by electrophoresis in $1 \%$ agarose gel. The gels were stained with ethidium bromide and photographed by Bio-IMAGING System. The PCR products were purified by TaKaRa Agarose Gel DNA Purification Kit Ver.2.0.

2.4. Sequencing and Phylogenetic Tree Construction. The products were sequenced by Shanghai Sangon Biological Engineering Technology and Service Co., Ltd. The sequences were aligned using Clustal $\mathrm{X}$, and further manually adjusted using BioEdit. The gained sequences should be ITS region and $18 \mathrm{~S}$ rDNA by homology investigation with BLAST on the website of NCBI (http://www.ncbi.nih.gov/) by defining the boundary and length [28]. The sequences were aligned in order to observe the resemblance and to analyze the differences using the software DNAMAN with default parameters. With the multialignment analysis, we applied the program MEGA 3.1 with Kimura's two-parameter model [29] to calculate the base composition, Kimura twoparameter distance and the ratio of sequence divergence. For phylogenetic analysis, we used MEGA3.1 (neighbor-joining method) to study the relationship of different species to construct the phylogenetic tree, and detect the degree of bootstrap confidence from 1000 replicates. For comparative analysis, sequences were taken from the GenBank, of which entrance numbers were shown in Table 4.

\section{Results}

3.1. Splicing of ITS Region and $18 S$ rDNA Sequences Fragments. With the primers mentioned above, the genomic of the ITS region and 18S rDNA fragments were successfully amplified (Figure 1). We got the overall length of ITS region and $18 \mathrm{~S}$ rDNA sequences about $U$. prolifera, $U$. pertusa, and M. grevillei.

3.2. ITS Region and 18S rDNA Sequences of the Three Species. The base size of $U$. prolifera was $536 \mathrm{bp}$ in ITS and $1718 \mathrm{bp}$ in 18S. And the base size of M. grevillei was $541 \mathrm{bp}$ in ITS and $1755 \mathrm{bp}$ in $18 \mathrm{~S}$. And the base size of $U$. pertusa was $567 \mathrm{bp}$ in ITS and $1761 \mathrm{bp}$ in 18S. The base sizes of the three species were almost the same in ITS region and $18 \mathrm{~S}$ rDNA. After sequencing the ITS region and $18 \mathrm{~S}$ rDNA, we got the accession numbers from GenBank. For comparative analysis, sequences of other sixteen species were also taken from the GenBank. All these data were shown in Table 2.

3.3. Base Composition of ITS Region and $18 \mathrm{~S}$ rDNA Sequences. The base composition of ITS region and the content of $\mathrm{G}+\mathrm{C}$ are shown in Table 3. And the base composition of $18 \mathrm{~S}$ rDNA and the content of $\mathrm{G}+\mathrm{C}$ are shown in Table 4 . The ITS region content of $\mathrm{G}+\mathrm{C}$ was about $58.45 \%$ in average in nineteen species. However, the content of $\mathrm{G}+\mathrm{C}$ varied obviously from $51.65 \%$ to $65.78 \%$ in ITS region while $18 \mathrm{~S}$ rDNA content of $\mathrm{G}+\mathrm{C}$ was about $48.98 \%$ in average in nineteen species. Comparing with the content of $\mathrm{G}+\mathrm{C}$ in ITS region, the content of $\mathrm{G}+\mathrm{C}$ in $18 \mathrm{~S}$ was approximately concentrated upon $49 \%$. The ITS region content of base $\mathrm{G}$ and $\mathrm{C}$ in average in nineteen species is obviously higher than $\mathrm{A}$ and $\mathrm{T}$.

3.4. Genetic Distance in Interspecies. Comparing the ITS region and $18 \mathrm{~S} \mathrm{rDNA}$ sequence obtained in this study and other species retrieved from GenBank, the results of the genetic distance and the ratio of sequence divergence are shown in Tables 5 and 6. U. pertusa and U. prolifera had closer genetic relationship with genetic distance of 0.007 in $18 \mathrm{~S}$ rDNA. While, its had further genetic distance in ITS.

A comparison of the sequences of the ITS of the three strains evaluated in this study to those of other species of green algal retrieved from GenBank is shown in Table 5. Obviously, CC, UC, HT, UL, EI, SC, UF, UO, and PPE are subordinate to Ulvaceae. The region distance (ranged form 0.189 to 0.035 ) and the ratio of sequence divergence (ranged from 0.026 to 0.010 ) are lower than those comparisons within other 10 species from different families. Particularly prominent, CC, HT, and UC had the closest relationship 
TABle 3: Base composition of ITS region.

\begin{tabular}{|c|c|c|c|c|c|}
\hline Taxon & $\mathrm{A}(\%)$ & $\mathrm{T}(\%)$ & $\mathrm{G}(\%)$ & $\mathrm{C}(\%)$ & $\mathrm{G}+\mathrm{C}(\%)$ \\
\hline Ulva lactuca & 21.37 & 15.88 & 28.24 & 34.51 & 62.75 \\
\hline Klebsormidium flaccidum & 21.78 & 19.42 & 28.71 & 30.10 & 58.81 \\
\hline Chlorella vulgaris & 20.00 & 23.45 & 25.32 & 31.22 & 56.55 \\
\hline Mantoniella squamata & 22.76 & 21.27 & 28.17 & 27.80 & 55.97 \\
\hline Ulva prolifera & 20.15 & 17.16 & 28.92 & 33.77 & 62.69 \\
\hline Monostroma grevillei & 22.92 & 21.26 & 24.95 & 30.87 & 55.82 \\
\hline Paulschulzia pseudovolvox & 24.26 & 24.09 & 24.75 & 26.90 & 51.65 \\
\hline Trebouxia asymmetrica & 20.27 & 26.93 & 26.48 & 26.32 & 52.80 \\
\hline Kornmannia leptoderma & 22.78 & 22.06 & 26.16 & 29.00 & 55.16 \\
\hline Monostroma nitidum & 24.18 & 23.26 & 25.27 & 27.29 & 52.56 \\
\hline Blidingia minima & 22.45 & 22.08 & 25.55 & 29.93 & 55.47 \\
\hline Enteromorpha intestinalis & 18.85 & 18.85 & 28.84 & 33.46 & 62.29 \\
\hline Ulva fenestrata & 20.04 & 17.12 & 28.99 & 38.85 & 62.84 \\
\hline Chloropelta caespitosa & 20.51 & 19.15 & 29.06 & 31.28 & 60.34 \\
\hline Ulvaria obscura var. blyttii & 20.42 & 18.13 & 28.44 & 33.02 & 61.45 \\
\hline Ulothrix zonata & 23.98 & 24.18 & 24.56 & 27.27 & 51.84 \\
\hline Ulva pertusa & 18.87 & 15.34 & 30.34 & 35.45 & 65.78 \\
\hline Ulva californica & 20.41 & 19.11 & 28.39 & 32.10 & 60.48 \\
\hline Percursaria percursa & 19.86 & 14.81 & 29.62 & 35.71 & 65.33 \\
\hline Average & 21.36 & 20.19 & 27.41 & 31.31 & 58.45 \\
\hline
\end{tabular}

TABLE 4: Base composition of $18 S$ rDNA.

\begin{tabular}{|c|c|c|c|c|c|}
\hline Taxon & $\mathrm{A}(\%)$ & $\mathrm{T}(\%)$ & $\mathrm{G}(\%)$ & $\mathrm{C}(\%)$ & $\mathrm{G}+\mathrm{C}(\%)$ \\
\hline Ulva lactuca & 26.37 & 24.50 & 28.78 & 20.35 & 49.13 \\
\hline Klebsormidium flaccidum & 26.08 & 26.80 & 26.53 & 20.59 & 47.11 \\
\hline Chlorella vulgaris & 24.97 & 25.42 & 27.64 & 21.97 & 49.61 \\
\hline Mantoniella squamata & 26.01 & 26.80 & 26.74 & 20.45 & 47.19 \\
\hline Ulva prolifera & 24.80 & 25.67 & 27.76 & 21.77 & 49.53 \\
\hline Monostroma grevillei & 25.13 & 26.55 & 27.35 & 20.97 & 48.32 \\
\hline Paulschulzia pseudovolvox & 24.91 & 25.49 & 28.02 & 21.58 & 49.60 \\
\hline Trebouxia asymmetrica & 25.06 & 26.00 & 27.34 & 21.60 & 48.94 \\
\hline Kornmannia leptoderma & 26.51 & 24.10 & 28.92 & 20.48 & 49.40 \\
\hline Monostroma nitidum & 26.17 & 24.83 & 28.84 & 20.16 & 49.00 \\
\hline Blidingia minima & 26.34 & 23.66 & 29.14 & 20.86 & 50.00 \\
\hline Enteromorpha intestinalis & 24.87 & 25.74 & 27.78 & 21.61 & 49.39 \\
\hline Ulva fenestrata & 26.30 & 24.43 & 28.84 & 20.43 & 49.27 \\
\hline Chloropelta caespitosa & 26.44 & 24.43 & 28.84 & 20.29 & 49.13 \\
\hline Ulvaria obscura var. blyttii & 26.44 & 24.30 & 28.97 & 20.29 & 49.27 \\
\hline Ulothrix zonata & 25.09 & 27.01 & 27.07 & 20.83 & 47.90 \\
\hline Ulva pertusa & 24.70 & 25.95 & 27.77 & 21.58 & 49.35 \\
\hline Ulva californica & 26.30 & 24.57 & 28.84 & 20.29 & 49.13 \\
\hline Percursaria percursa & 26.17 & 24.43 & 28.97 & 20.43 & 49.40 \\
\hline Average & 25.72 & 25.30 & 28.11 & 20.87 & 48.98 \\
\hline
\end{tabular}

among each other because of the lower region distance (HT/CC 0.057; HT/UC 0.057; CC/UC 0.035) and the ratio of sequence divergence (HT/CC 0.012; HT/UC 0.012; CC/UC 0.010). These data illustrate HT/UC/CC has extremely related species. According to other Ulva species, the sequence homology of these three species is closer which verified
$U$. prolifera and C. caespitosa belonged to Ulva genera. On the other hand, JM, UZ, BM, MN, and KL had higher homology relationship within each other, the region distance ranged from 0.335 to 0.133 , and the ratio of sequence divergence ranged from 0.033 to 0.021 . The data are relatively stable, and in these five species, JM/UZ is the closest pair because of 
TABLE 5: Kimura 2-parameter ITS region distance (below) and the ratio of sequence divergence (above).

\begin{tabular}{|c|c|c|c|c|c|c|c|c|c|c|c|c|c|c|c|c|c|c|c|}
\hline Spec & UL & JM & HT & SC & UZ & UO & $\mathrm{CC}$ & UF & EI & $\mathrm{BM}$ & $\mathrm{MN}$ & $\mathrm{KL}$ & TA & $\mathrm{PP}$ & MS & UC & PPE & $\mathrm{CV}$ & KF \\
\hline UL & & 0.039 & 0.017 & 0.019 & 0.038 & 0.025 & 0.016 & 0.019 & 0.015 & 0.039 & 0.041 & 0.038 & 0.053 & 0.048 & 0.057 & 0.014 & 0.024 & 0.049 & 0.049 \\
\hline $\mathrm{JM}$ & 0.377 & & 0.037 & 0.040 & 021 & 0.037 & 0.037 & 0.038 & 037 & 0.025 & 0.032 & 0.033 & & 0.048 & 0.048 & 0.039 & 0.035 & 0.045 & 0.044 \\
\hline HT & 0.105 & 0.338 & & 0.018 & 0.037 & 0.023 & 0.012 & 0.016 & & 0.039 & & 0.039 & & & 0.054 & 0.012 & 0.023 & 0.046 & 0.047 \\
\hline SC & 0.118 & 0.369 & 0.102 & & .041 & 0.026 & 0.019 & 0.015 & 0.018 & 0.042 & 0.044 & 0.042 & 0.053 & 0.049 & 0.059 & 0.017 & 0.023 & 0.046 & 0.051 \\
\hline UZ & 0.364 & 0.133 & 0.355 & 0.398 & & 0.036 & 0.037 & 0.037 & .039 & 0.022 & 0.028 & 0.033 & 0.046 & 0.049 & 0.052 & 0.038 & 0.037 & 0.043 & 0.045 \\
\hline UO & 0.196 & 0.335 & 0.163 & 0.181 & 0.333 & & 0.025 & 0.024 & & 0.035 & & 0.040 & & 0.049 & 0.059 & 0.025 & 0.016 & .044 & 0.047 \\
\hline CC & & & & & & 0.189 & & & & & & & & & & & & & 0.048 \\
\hline UF & 0.118 & 0.346 & 0.089 & 0.076 & 0.360 & 0.178 & 0.099 & & & 0.039 & 0.040 & & & & 0.054 & & & & 0.048 \\
\hline EI & 0.070 & 0.348 & 0.085 & 0.112 & 0.360 & 0.185 & 0.079 & 0.109 & & 0.039 & 0.040 & 0.038 & 0.050 & 0.045 & 0.056 & 0.015 & 0.022 & 0.048 & 0.048 \\
\hline $\mathrm{BM}$ & 0.368 & 0.189 & 0.360 & 0.398 & 0.146 & 0.329 & 0.354 & 0.369 & 0.363 & & 0.029 & 0.030 & 0.045 & 0.049 & 0.053 & 0.039 & 0.038 & 0.046 & 0.049 \\
\hline $\mathrm{MN}$ & & 0.257 & 0.370 & 0.416 & & 0.349 & 0.378 & 0.374 & 0.374 & 0.243 & & & & & 0.053 & & & & 0.046 \\
\hline $\mathrm{KL}$ & & & & & & & & & & & & & & & 0.055 & & & & 0.048 \\
\hline TA & & & & & & & & & & & & & & & 0.053 & & & & 0.049 \\
\hline PP & 0.477 & 0.479 & 0.440 & 0.489 & 0.475 & 0.480 & 0.477 & 0.465 & 0.444 & 0.478 & 0.465 & 0.459 & 0.315 & & 0.055 & 0.048 & 0.048 & 0.048 & 0.047 \\
\hline MS & 0.549 & 0.474 & 0.527 & 0.571 & 0.520 & 0.558 & 0.551 & 0.537 & 0.548 & 0.534 & 0.529 & 0.565 & 0.519 & 0.554 & & 0.055 & 0.056 & 0.059 & 0.042 \\
\hline UC & & 0.365 & 0.057 & 0.099 & 0.363 & 0.181 & 0.035 & 0.092 & & 0.368 & 0.393 & 0.394 & & 0.476 & 0.538 & & 0.023 & 0.048 & 0.048 \\
\hline PPE & & & & 0.167 & & & & & & & & 0.391 & & & 0.539 & 0.174 & & & 0.045 \\
\hline $\mathrm{CV}$ & 0.476 & 0.423 & 0.441 & 0.448 & 0.397 & 0.434 & 0.460 & 0.443 & 0.456 & 0.429 & 0.383 & 0.483 & 0.480 & 0.458 & 0.611 & 0.470 & 0.435 & & 0.049 \\
\hline $\mathrm{KF}$ & 0.492 & 0.432 & 0.485 & 0.508 & 0.446 & 0.460 & 0.502 & 0.478 & 0.479 & 0.490 & 0.452 & 0.473 & 0.501 & 0.468 & 0.389 & 0.496 & 0.443 & 0.506 & \\
\hline
\end{tabular}

Note: UL, U. lactuca; KF, K. flaccidum; CV, C. vulgaris; MS, M. squamata; HT, U. prolifera; JM, M. grevillei; PP, P. pseudovolvox; TA, T. asymmetrica; KL, K. leptoderma; MN, M. nitidum; BM, B. minima; EI, E. intestinalis; UF, U. fenestrate; CC, C. caespitosa; UO, U. obscura var. blyttii; UZ, U. zonata; SC, U. pertusa; UC, U. californica; PPE, P. percursa.

TABLE 6: Kimura 2-parameter 18S rDNA distance (below) and the ratio of sequence divergence (above).

\begin{tabular}{|c|c|c|c|c|c|c|c|c|c|c|c|c|c|c|c|c|c|c|c|}
\hline ies & II & CC & M & C & M & SC & $\mathrm{HT}$ & $\mathrm{CV}$ & UL & PPE & JO & UF & TA & MS & PP & KF & UZ & $\mathrm{MN}$ & KL \\
\hline EI & & .002 & 0.010 & .000 & 009 & 0.003 & 0.003 & .011 & 0.002 & 0.004 & 0.005 & 0.002 & 0.013 & 0.014 & 0.011 & 0.013 & 0.009 & 0.009 & 0.008 \\
\hline & 0.003 & & 010 & 002 & 010 & 002 & 002 & & 0.002 & 004 & 0.005 & 0.002 & & 0.014 & 0.011 & 0.014 & 0.009 & 0.009 & 0.008 \\
\hline BM & 0.070 & 0.073 & & 0.010 & 010 & 0.010 & 0.010 & .012 & 0.010 & 0.010 & 0.010 & 0.010 & 0.013 & 0.015 & $0 . .012$ & 0.015 & 0.010 & 0.010 & 0.006 \\
\hline UC & .000 & 0.003 & 0.070 & & 0.009 & 0.003 & 0.003 & & 0.002 & 0.004 & 0.005 & 0.002 & & & & & 0.009 & 0.009 & 0.008 \\
\hline & 64 & .067 & 0.069 & 0.064 & & 0.010 & 0.010 & & 0.010 & 0.010 & 0.009 & 0.010 & & 0.013 & & & 0.003 & 0.005 & 0.008 \\
\hline & 007 & 0.004 & 0.078 & 0.007 & 0.072 & & 0.003 & 0.011 & 0.003 & 0.005 & 0.005 & 0.003 & 0.013 & 0.015 & 0.011 & 0.014 & 0.009 & 0.009 & 0.009 \\
\hline $\mathrm{T}$ & 0.005 & 0.003 & 0.076 & 0.005 & 0.070 & 0.007 & & 0.011 & 0.003 & 0.004 & 0.005 & 0.003 & 0.013 & 0.015 & 0.011 & 0.014 & 0.009 & .009 & 0.009 \\
\hline $\mathrm{CV}$ & 086 & 0.089 & & 0.086 & 0.067 & 0.093 & 0.092 & & 0.011 & & 0.011 & 0.011 & & & & & 0.009 & & 0.011 \\
\hline & 04 & & & .004 & 069 & & 0.005 & & & & 0.004 & & & & & & 0.009 & & 0.008 \\
\hline & 011 & .014 & 072 & 0.011 & 066 & 0.018 & 0.017 & 0.083 & 0.015 & & & 0.004 & & & & & 0.009 & 0.009 & 0.008 \\
\hline 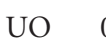 & 0.018 & 0.017 & 0.073 & 0.018 & 0.064 & 0.021 & 0.019 & 0.091 & 0.017 & 0.012 & & 0.004 & 0.012 & 0.014 & 0.012 & 0.014 & 0.009 & 0.009 & 0.008 \\
\hline & 0.004 & 0.003 & & 0.004 & & & 0.005 & & 0.000 & & 0.017 & & 0.013 & & & & 0.009 & & 0.008 \\
\hline TA & 0.113 & 0.116 & 0.115 & 0.113 & 0.075 & 0.121 & 0.119 & 0.054 & 0.114 & 0.108 & 0.105 & 0.114 & & 0.011 & 0.011 & 0.011 & 0.010 & 0.011 & 0.012 \\
\hline MS & 141 & & & 0.141 & & & 0.148 & & 0.1 & & 0.141 & 0.146 & 0.087 & & & & 13 & & 0.014 \\
\hline PP & & & & & & & & & & & 0.094 & 0.090 & & 0.102 & & & & & 0.011 \\
\hline & 0.124 & 0.127 & & 0.124 & 0.111 & 0.132 & 0.130 & 0.078 & 0.129 & & 0.129 & 0.129 & 0.086 & 0.084 & 0.098 & & 0.012 & 0.012 & 0.014 \\
\hline $\mathrm{UZ}$ & 0.058 & 0.061 & 0.067 & 0.058 & 0.008 & 0.066 & 0.064 & 0.063 & 0.063 & 0.060 & 0.061 & 0.063 & 0.074 & 0.109 & 0.072 & 0.104 & & 0.004 & 0.008 \\
\hline $\mathrm{MN}$ & 0.060 & 0.063 & 0.069 & 0.060 & 0.018 & 0.067 & 0.066 & 0.063 & 0.064 & & 0.066 & 0.064 & 0.078 & 0.114 & 0.073 & 0.104 & 0.011 & & 0.008 \\
\hline KL & 0.054 & 0.057 & 0.034 & 0.054 & 0.046 & 0.061 & 0.060 & 0.084 & 0.058 & 0.054 & 0.054 & 0.058 & 0.092 & 0.130 & 0.085 & 0.123 & 0.046 & 0.049 & \\
\hline
\end{tabular}

Note: UL, U. lactuca; KF, K. flaccidum; CV, C. vulgaris; MS, M. squamata; HT, U. prolifera; JM, M. grevillei; PP, P. pseudovolvox; TA, T. asymmetrica; KL, K. leptoderma; MN, M. nitidum; BM, B. minima; EI, E. intestinalis; UF, U. fenestrate; CC, C. caespitosa; UO, U. obscura var. blyttii; UZ, U. zonata; SC, U. pertusa; UC, U. californica; PPE, P. percursa. 


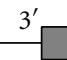

$\overrightarrow{\mathrm{CRN} 5} \quad 1100-1130 \mathrm{bp} \quad \overleftarrow{1137}$

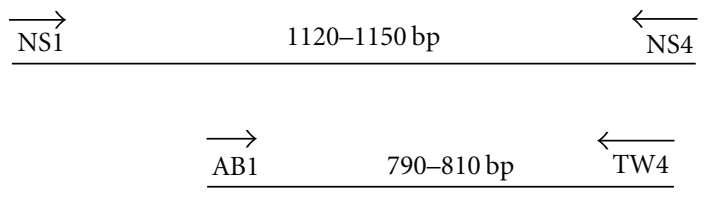

$\overrightarrow{\text { MonS }} \quad 270-280$ bp $\overleftarrow{\text { MonA }}$

$\overrightarrow{\mathrm{NS5}} \quad 560-630 \mathrm{bp} \quad \overleftarrow{\mathrm{NS} 8}$

Figure 1: Splicing of $18 \mathrm{~S}$ rDNA sequences fragments with the primers mentioned in Table 1.

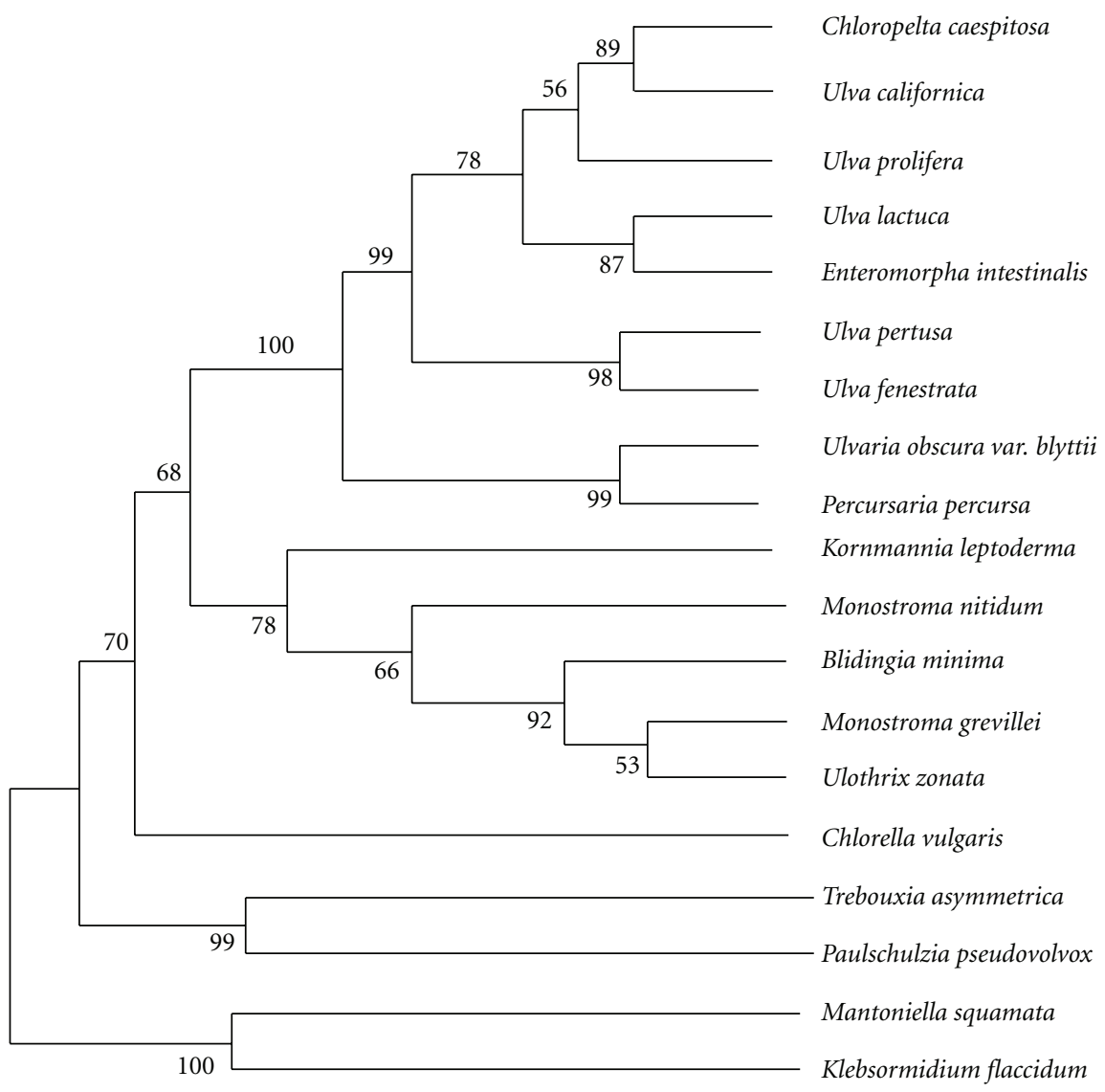

FIGURE 2: NJ phylogenetic tree constructed from ITS sequences.

the lowest region distance $(0.133)$ and the ratio of sequence divergence (0.021).

A comparison of the sequences of the ITS of the three strains evaluated in this study to those of other species of green algal retrieved from GenBank is shown in Table 6. The same result with ITS, IE, CC, UC, SC, HT, UL, PPE, UO, and UF are subordinate to Ulvaceae. The region distance (ranged form 0.021 to 0.000 ) and the ratio of sequence divergence (ranged from 0.005 to 0.000 ) are lower than those comparisons within other 10 species from different families. Meanwhile, JM, UZ, BM, MN, and KL had higher homology relationship within each other, the region distance ranged 


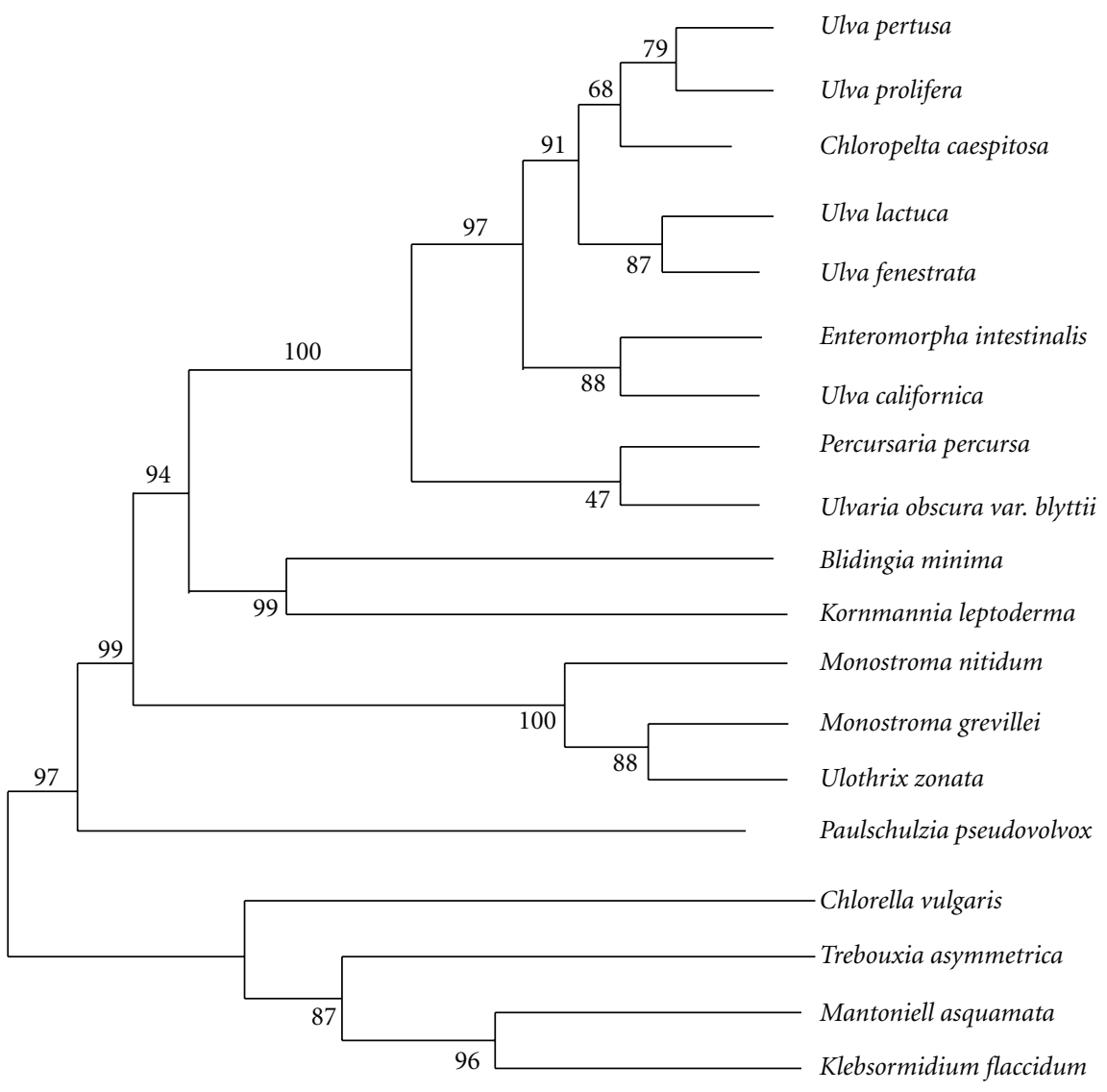

FIGURE 3: NJ phylogenetic tree constructed from $18 \mathrm{~S}$ sequences.

from 0.069 to 0.008 , and the ratio of sequence divergence ranged from 0.010 to 0.004 .

3.5. Phylogenetic Tree Analysis. From the results of NJ phylogenetic tree constructed from ITS and $18 \mathrm{~S}$ sequences (Figures 2 and 3), U. pertusa and U. prolifera belong to one branch. The homology of U. pertusa, and U. prolifera was obviously higher than M. grevillei.

The tree resulting from $\mathrm{NJ}$ analysis of the combined data of ITS is shown in Figure 2. As in previous analyses, the Ulvaceae and JM/UZ/BM/MN/KL were well supported. C. caespitosa and $U$. californica formed a tiny branch and $U$. prolifera joined them. U. lactuca and E. intestinalis composed another branch as $U$. pertusa and $U$. fenestrata did. There is strong support for the grouping of C. caespitosa with $U$. californica and $U$. prolifera in this phylogenetic tree, which coincided with the result from Hayden and Waaland [30]. M. grevillei and $U$. zonata formed one branch and then joined with B. minima, M. nitidum, and K. leptoderma forming one lager clade. The NJ tree and distance data both supported that M. grevillei has closer phylogenetic relation with $U$. zonata than $M$. nitidum.

The tree resulting from NJ analysis of $18 \mathrm{~S}$ sequence is shown in Figure 3. In this tree, there is still strong support for the grouping of $C$. caespitosa with $U$. californica and $U$. prolifera while $U$. pertusa and $U$. prolifera formed a branch and $C$. caespitosa joined with them, which is different from the result of ITS in Figure 2. Additionally, E. intestinalis came to the same branch with $U$. californica which confirmed well with the data of region distance and the ratio of sequence divergence in Table 6. B. minima and K. leptoderma became one clade. M. grevillei and U. zonata formed one branch again and $M$. nitidum joined them firstly. In the NJ tree of $18 \mathrm{~S}$, the smaller branch of B. minima and K. leptoderma is further away from the bigger one of $M$. nitidum, $M$. grevillei, and $U$. zonata, which is a more significant diversity compared with the NJ tree of ITS.

\section{Discussions}

During the past three decades, green tide has been gaining in scale and frequency in both marine and estuary environment all over the world. And in recent years, green tide massively occurred in China Yellow Sea. The main species involved in green tides are Ulva sp. and Enteromorpha sp.

The traditional taxonomy uses the morphology characters as the criterion. The thallus that consists of two layer cells is the genus Ulva while the monolayer cell form hollow tubular is Enteromorpha. But the Enteromorpha internal tubular thallus contained villiform protuberances and meshwork structures which were composed of glycoprotein. When the number of cells in cross-section of tubular thallus reached 
$30-50 \mathrm{~h}$, the villiform protuberances disappeared and the meshwork structures became tight, then the mural cells of tubular thallus adhered and the foliolose thallus formed [31]. In culture studies of European Ulva species, Gayral [32] observed the development of both tubular and blade thalli from single populations of zoospores and parthenogenetic gametes.

Ulva sp. has wide acclimatization and can grow well in a broad range of temperatures and salinities, but change morphological characteristics easily in response to the environment [16]. Various morphological changes in the intraspecies and less differences among interspecies make identification of Ulva sp. using classical taxonomic methods very difficult $[22,23]$.

Molecular biology methods such as chloroplast $r b c \mathrm{~L}$, nuclear ITS, and $18 \mathrm{~S}$ rDNA sequence analysis [5, 26, 27], alone or in combination with morphological methods, have been applied to species identification since green tides have occurred in the Yellow Sea. Despite multidisciplinary study, classification of the main causative species of green tides is still difficult. Several researchers have suggested that green tides are formed by an Ulva linza-procera-prolifera (LPP) complex instead of individual species $[5,17]$.

Although the thallus of $U$. pertusa is thick with many holes, it is different from $U$. prolifera in morphology. From the phylogenetic tree constructed from $18 \mathrm{~S}$ sequences, it can be found that $U$. pertusa and $U$. prolifera group in one branch while $U$. lactuca, $U$. fenestrate, and $U$. californica are in another branch. From the phylogenetic tree constructed from ITS sequences, $U$. prolifera and $U$. pertusa are not in one branch. But $U$. pertusa and $U$. fenestrate grouped in one branch. No matter if the phylogenetic tree is constructed from ITS sequences or $18 \mathrm{~S}$ sequences, it is clear that the clade of Ulvaceae is comprised of Chloropelta, Enteromorpha, Percursaria, Ulva and Ulvaria. These results are consistent with that of Hayden and Waaland [30] which proved that in different areas it had the same conclusion.

Hayden et al. [21] preferred that Enteromorpha should be transferred to Ulva and Chloropelta, caespitosa should be named Ulva tanneri according to the molecular phyletic evolution research. From the phylogenetic tree constructed from ITS and $18 \mathrm{~S}$ sequences in our study, it is obviously showed that Enteromorpha and Ulva have closer phyletic evolution relationship.

Trees inferred from phylogenetic analysis of ITS and 18S both showed that Monostroma nitidum and Monostroma grevillei were not in one branch while Monostroma grevillei and Ulothrix zonata are in one branch. Monostroma grevillei has a closer $18 \mathrm{~S}$ genetic distance with Ulothrix zonata (0.008) than with Monostroma nitidum (0.018). The same result is in ITS genetic distance with Ulothrix zonata (0.133), other than that with Monostroma nitidum (0.257). These results are also consistent with that of Hayden and Waaland [30].

So, we can make use of sequences not only in $18 \mathrm{~S}$ rDNA to analyse genera, but also in ITS region and other sequences, such as $28 \mathrm{~S}$ rDNA and chloroplast $r b c \mathrm{~L}$, all these together are the better way to analyze the whole phyletic evolution relationship.

\section{Acknowledgments}

This paper was supported by the National Scientific Foundations of China (Grant no. 30570125) and the Key Construction Laboratory of Marine Biotechnology of Jiangsu Province (Grant no. 2010HS03). L. Zijie and L. Zhongheng contributed equally to this work.

\section{References}

[1] D. Schories and K. Reise, "Germination and anchorage of Enteromorpha spp. in sediments of the Wadden Sea," Helgoland Marine Research, vol. 47, no. 3, pp. 275-285, 1993.

[2] R. L. Fletcher, "The occurrence of 'green tides", in Marine Benthic Vegetation: Recent Changes and the Effects of Eutrophication, W. Schramm and P. H. Nienhuis, Eds., Ecological Studies, vol. 123, pp. 7-43, Springer, Berlin, Germany, 1996.

[3] T. A. Nelson, K. Haberlin, A. V. Nelson et al., "Ecological and physiological controls of species composition in green macroalgal blooms," Ecology, vol. 89, no. 5, pp. 1287-1298, 2008.

[4] T. A. Nelson, J. Olson, L. Imhoff, and A. V. Nelson, "Aerial exposure and desiccation tolerances are correlated to species composition in 'green tides' of the Salish Sea (northeastern Pacific)," Botanica Marina, vol. 53, no. 2, pp. 103-111, 2010.

[5] P. Jiang, J. F. Wang, Y. L. Cui, Y. X. Li, H. Z. Lin, and S. Qin, "Molecular phylogenetic analysis of attached Ulvaceae species and free-floating Enteromorpha from Qingdao coasts in 2007," Chinese Journal Oceanology and Limnology, vol. 26, no. 3, pp. 276-279, 2008.

[6] S. Sun, J. F. Wang, C. L. Li et al., "Emerging challenges: massive green algae blooms in the Yellow Sea," Nature Precedings, 2008.

[7] L. P. Ding, X. G. Fei, Q. Q. Lu, Y. Y. Deng, and S. X. Lian, "The possibility analysis of habitats, origin and reappearance of bloom green alga (Enteromorpha prolifera) on inshore of western Yellow Sea," Chinese Journal Oceanology and Limnology, vol. 27, no. 3, pp. 421-424, 2009.

[8] N. H. Ye, Z. M. Zhang, X. S. Jin, and Q. Y. Wang, "China is on the track tackling Enteromorpha spp. forming green tide," Nature Precedings, 2008.

[9] D. Y. Liu, J. K. Keesing, Q. G. Xing, and P. Shi, "World's largest macroalgal bloom caused by expansion of seaweed aquaculture in China," Marine Pollution Bulletin, vol. 58, no. 6, pp. 888-895, 2009.

[10] H. F. Link, "Epistola ad virum celeberrimum Nees ab Esenbeck. de algis aquaticis, in genera Disponendis," in Horae Physicae Berolinense, C. G. D. Nees von Esenbeck, Ed., pp. 1-8, Bonnae, Bonn, Germany, 1820.

[11] E. Nic Dhonncha and M. D. Guiry, "Algaebase: documenting seaweed biodiversity in Ireland and the world," Biology and Environment, vol. 102, no. 3, pp. 185-188, 2002.

[12] C. K. Tseng and J. F. Zhang, "Economic seaweeds of northern China," Journal of Shandong University (Natural Science), vol. 2, pp. 57-82, 1952 (Chinese).

[13] C. K. Tseng and J. F. Zhang, "The economic seaweeds flora of the Yellow Sea and East Sea," Oceanologia et Limnologia Sinica, vol. 2, pp. 43-52, 1959 (Chinese).

[14] C. K. Tseng, D. R. Zhang, and J. F. Zhang, China Economic Seaweeds Records, Science Press, Beijing, China, 1962.

[15] C. K. Tseng and J. F. Zhang, "A preliminary analytical study of the Chinese marine algal flora," Oceanologia et Limnologia Sinica, vol. 5, no. 3, pp. 245-253, 1963 (Chinese). 
[16] M. L. Dong, "A preliminary phytogeographical studies on Chinese species of Enteromorpha," Oceanologia et Limnologia Sinica, vol. 5, no. 1, pp. 46-51, 1963 (Chinese).

[17] T. J. White, T. Bruns, S. Lee, and J. Taylor, "Amplification and direct sequencing of fungal ribosomal RNA genes for phylogenetics," in PCR Protocols: A Guide to Methods and Applications, M. A. Innes, D. H. Gefland, J. J. Sninsky, and T. J. White, Eds., pp. 315-322, Academic Press, New York, NY, USA, 1990.

[18] G. C. Booton, G. L. Floyd, and P. A. Fuerst, "Polyphyly of tetrasporalean green algae inferred from nuclear smallsubunit ribosomal DNA," Journal of Phycology, vol. 34, no. 2, pp. 306-311, 1998.

[19] M. J. H. Van Oppen, Tracking trails by cracking codes, $\mathrm{Ph} . \mathrm{D}$. dissertation, University of Groningen, Groningen, The Netherlands, 1995.

[20] I. H. Tan, J. Blomster, G. Hansen et al., "Molecular phylogenetic evidence for a reversible morphogenetic switch controlling the gross morphology of two common genera of green seaweeds, Ulva and Enteromorpha," Molecular Biology and Evolution, vol. 16, no. 8, pp. 1011-1018, 1999.

[21] H. S. Hayden, J. Blomster, C. A. Maggs, P. C. Silva, M. J. Stanhope, and J. R. Waaland, "Linnaeus was right all along: Ulva and Enteromorpha are not distinct genera," European Journal of Phycology, vol. 38, no. 3, pp. 277-294, 2003.

[22] C. Bliding, "A critical study of European taxa in Ulvales. I. Capsosiphon, Percursaria, Blidingia, Enteromorpha," Opera Botanica, vol. 8, pp. 1-160, 1963.

[23] J. Blomster, C. A. Maggs, and M. J. Stanhope, "Molecular and morphological analysis of Enteromorpha intestinalis and E. compressa (Chlorophyta) in the British Isles," Journal of Phycology, vol. 34, no. 2, pp. 319-340, 1998.

[24] M. Hiraoka, M. Ohno, S. Kawaguchi, and G. Yoshida, "Crossing test among floating Ulva thalli forming 'green tide' in Japan,” Hydrobiologia, vol. 512, pp. 239-245, 2004.

[25] K. Niwa, A. Kobiyama, and T. Sakamoto, "Interspecific hybridization in the haploid blade-forming marine crop Porphyra (Bangiales, Rhodophyta): occurrence of allodiploidy in surviving F1 gametophytic blades," Journal of Phycology, vol. 46, no. 4, pp. 693-702, 2010.

[26] S. Shimada, M. Hiraoka, S. Nabata, M. Lima, and M. Masuda, "Molecular phylogenetic analyses of the Japanese Ulva and Enteromorpha (Ulvales, Ulvophyceae), with special reference to the free-floating Ulva," Phycological Research, vol. 51, no. 2, pp. 99-108, 2003.

[27] A. R. Sherwood, D. J. Garbary, and R. G. Sheath, "Assessing the phylogenetic position of the Prasiolales (Chlorophyta) using rbcL and 18S rRNA gene sequence data," Phycologia, vol. 39, no. 2, pp. 139-146, 2000.

[28] S. D. Shen, Y. Y. Li, X. J. Wu, and L. P. Ding, "Sequences and phylogeny analysis of $r b c L$ gene in marine Chlorophyta," Oceanic and Coastal Sea Research, vol. 9, pp. 145-150, 2010.

[29] S. Kumar, K. Tamura, and I. B. Jakobsen, "MEGA2: molecular evolutionary genetics analysis software," Bioinformatics, vol. 17, no. 12, pp. 1244-1245, 2001.

[30] H. S. Hayden and J. R. Waaland, "Phylogenetic systematics of the Ulvaceae (Ulvales, Ulvophyceae) using chloroplast and nuclear DNA sequences," Journal of Phycology, vol. 38, no. 6, pp. 1200-1212, 2002.

[31] J. W. Wang, A. P. Lin, S. D. Shen, and B. L. Yan, "Microscopic observation on the development of Enteromorpha prolifera (Chlorophyta)," Ecologic Science, vol. 25, no. 5, pp. 400-404, 2006.
[32] P. Gayral, "Sur le démembrement de l'actual genre Monostroma Thuret (Chlorophycées, Ulotrichales s.l.)," Comptes Rendus de l' Academie des Sciences, vol. 258, pp. 2149-2152, 1964. 

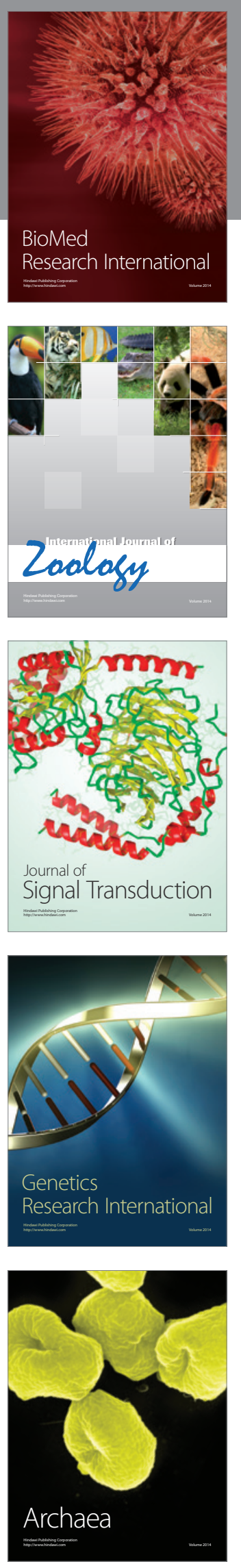
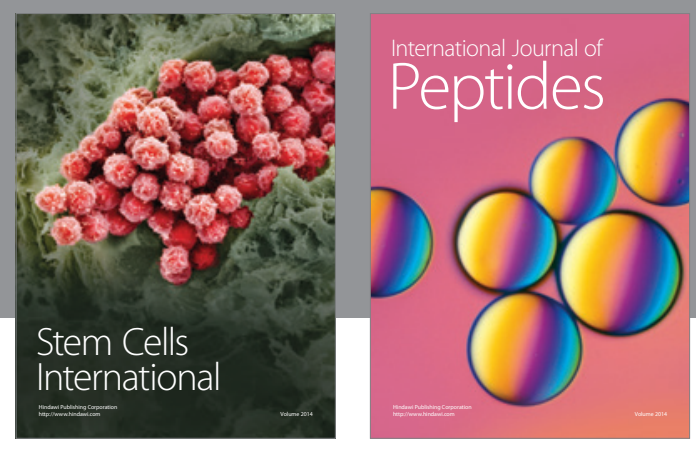

Submit your manuscripts at

http://www.hindawi.com
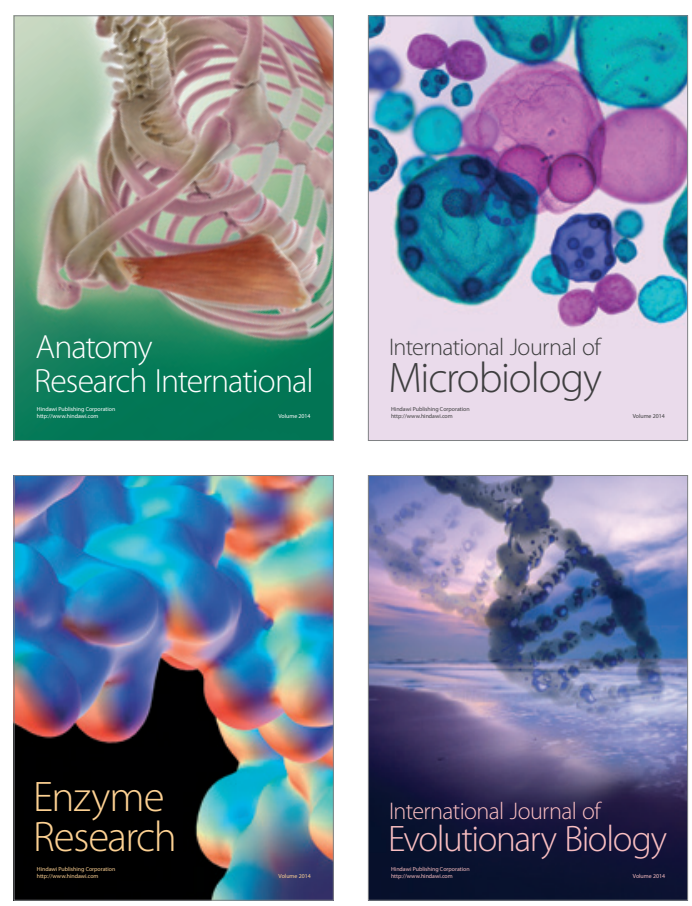
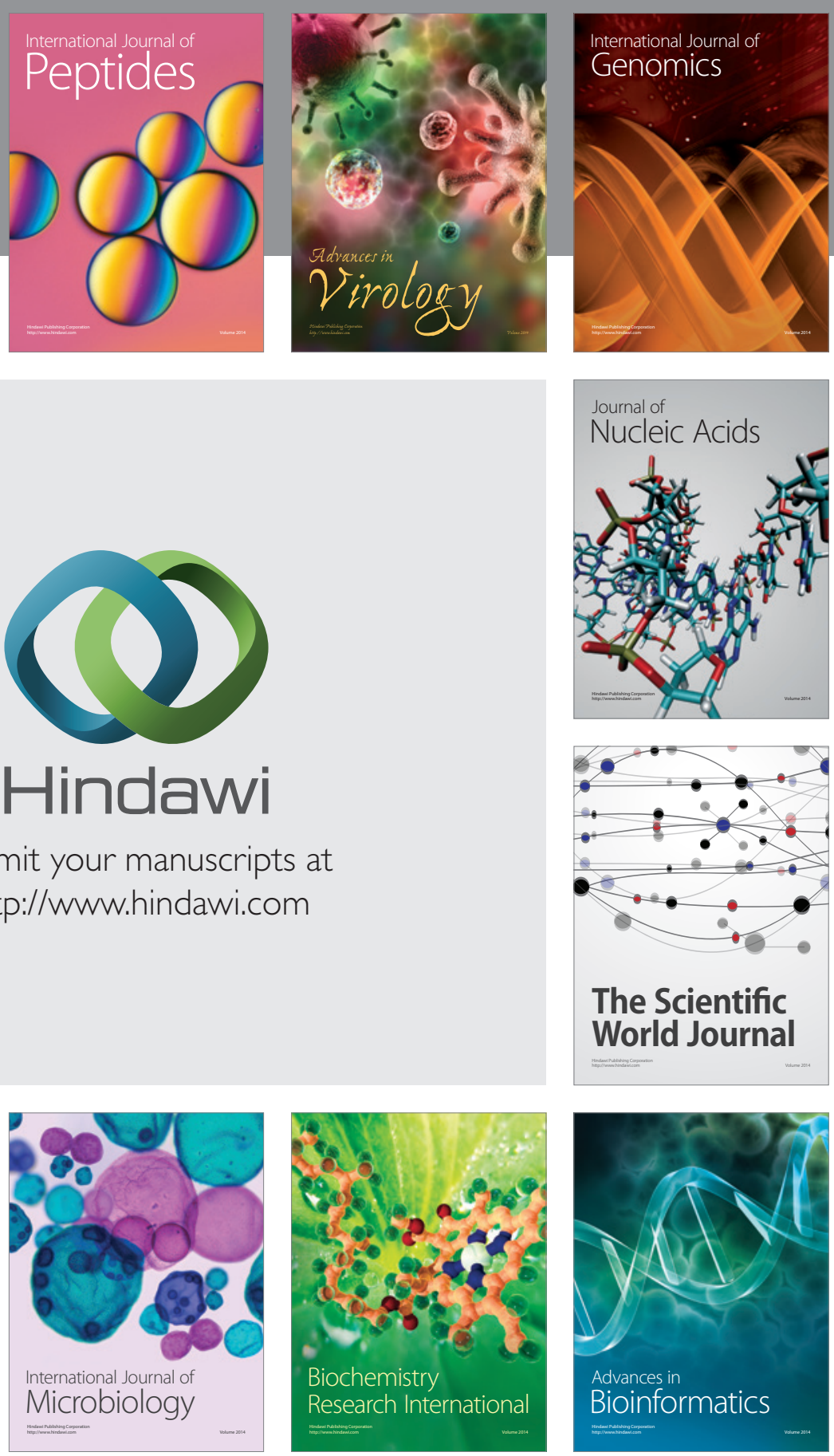

The Scientific World Journal
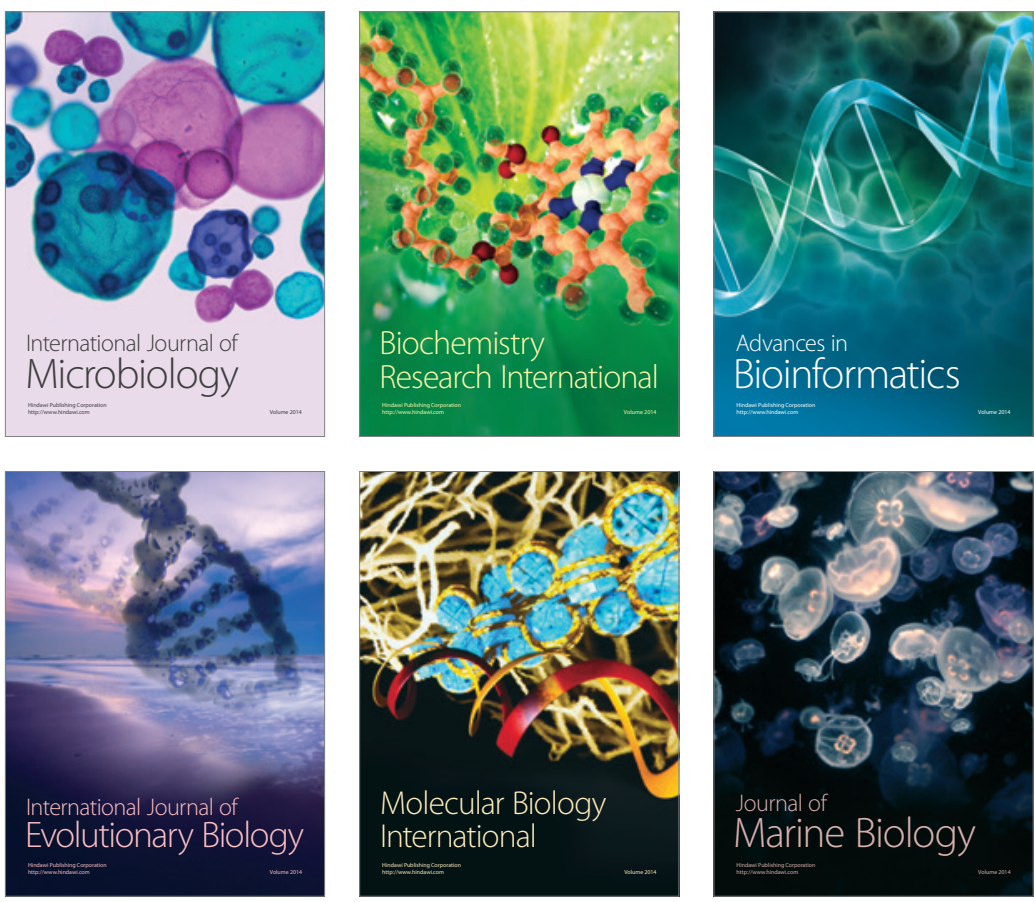